\title{
ARTIKELEN
}

\section{Signalen van de Hoge Raad naar de wetgever}

\author{
M.W.C. Feteris
}

\section{Inleiding, de verhouding tussen rechter en wetgever}

Als rechters zijn wij dagelijks bezig om wetten uit te leggen. Daarbij doen wij ons best om tot een uitleg te komen die zo goed mogelijk recht doet aan wat de wetgever heeft willen bereiken. Dat past bij de verhouding tussen de verschillende staatsmachten: politieke keuzes, keuzes over hoe de maatschappij moet worden ingericht en eventueel gestuurd, liggen bij de wetgever. Die is daartoe democratisch gelegitimeerd. Bij uitleg en toepassing van wettelijke regels behoort de rechter geen eigen agenda en geen eigen voorkeuren te hanteren. Je kunt het vergelijken met een dirigent die een symfonie van Beethoven uitvoert. Die heeft een zekere interpretatievrijheid. Als Beethoven Allegro erboven zet, is het een snel deel. De dirigent kan dan binnen een zekere bandbreedte iets sneller of langzamer uitkomen dan andere dirigenten, maar het moet geen langzaam deel worden. Het moet wel de muziek van Beethoven blijven. Bij de interpretatie van wetten moet de rechter als het ware in de huid van de wetgever kruipen. Hij moet zo goed mogelijk zien te begrijpen en aan te voelen wat de wetgever heeft beoogd en bedoeld. Hij is niet alleen als een 'bouche qui prononce les paroles de la loi', iemand die de woorden van de wet uitspreekt. Hij moet ook recht spreken in de geest van de wet, dans l'esprit des lois, om Montesquieu nog maar een keer te citeren.

In die zin zijn er belangrijke parallellen tussen het werk van wetgevingsambtenaren bij het maken van wetten en het onze als rechters bij de interpretatie ervan. Een rechter kan dat het best doen als hij begrijpt, doorgrondt wat de kunst van het wetgeven is. Ik denk dat de vereiste kennis en het benodigde begrip daarvoor in de Hoge Raad ook ruimschoots aanwezig zijn. Wij zijn ervan doordrongen hoe lastig en veeleisend het is om regels te formuleren. Soms formuleren wij zelf een reeks regels van ongeschreven recht waarvan we dan zelf als architect moeten optreden, bijvoorbeeld in het overzichtsarrest uit 2016 over de redelijke termijn in het bestuursrecht. ${ }^{1}$ Dan merk je bij uitstek hoe lastig het is om een duidelijk, samenhangend en werkbaar samenstel van regels op te bouwen. Op wat minder spectaculaire schaal lopen wij er ook regelmatig tegenaan als wij in een arrest een algemeen geformuleerde wettelijke regel moeten interpreteren. Houden we het dan smal, met een uitleg die alleen betrekking heeft op het berechte geval en eventueel op gevallen die daarop lijken? Of wijzen we een breder arrest, waarin die algemene regel ook voor andere categorieën gevallen wordt verduidelijkt en uitgewerkt? En hoe breed kunnen we het dan maken? Kunnen we alle mogelijke 
consequenties wel overzien als we het breed opschrijven? En formuleren we het dan vrij abstract of juist meer op concreet detailniveau? Dat zijn lastige keuzes die parallellen vertonen met de dilemma's waartegen een wetgevingsambtenaar aanloopt. Het is niet voor niets dat verschillende leden van de Hoge Raad ervaring hebben als wetgevingsambtenaar. Ook brengen de president van en de procureurgeneraal bij de Hoge Raad met enige regelmaat op verzoek van de betrokken minister wetgevingsadviezen uit, vooral over kwesties van procesrecht en rechterlijke organisatie. Ons eigen tuintje zal ik maar zeggen. Sinds een aantal jaren publiceren wij die adviezen ook op onze internetsite, uit overwegingen van openheid en transparantie.

Het is inmiddels vrijwel onomstreden dat de rechter met zijn uitleg van de wet ook iets toevoegt, iets extra's doet en dus een rechtsvormende taak heeft. ${ }^{2}$ De wetgever is daar ook van uitgegaan in de artikelen 80a en 81 van de Wet RO, waarin de HR mogelijkheden worden geboden voor verkorte en vereenvoudigde afdoening in zaken die geen vragen oproepen in het belang van de rechtseenheid of de rechtsontwikkeling. Omdat de rechter niet mag weigeren een beslissing te nemen, is het zelfs onvermijdelijk dat hij het recht ontwikkelt. In de zaak Hutchinson overwoog het EHRM dat 'in the Convention States the progressive development of the law through judicial interpretation is a well entrenched and even a necessary part of legal tradition'. ${ }^{3}$ Ontwikkeling en vorming van het recht zijn daarmee een gezamenlijke verantwoordelijkheid van rechter en wetgever. ${ }^{4}$ Men spreekt wel van partners in law making. ${ }^{5}$ Dat verloopt niet optimaal als je vanuit twee gesloten ivoren torens opereert. Met eerbiediging van de uiteenlopende verantwoordelijkheden van de verschillende staatsmachten is het goed om daarover te communiceren, contact daarover te hebben, van elkaar te weten wat je doet en wat er leeft. Om elkaar soms de bal toe te spelen. De wetgever formuleert regelmatig open normen met de uitdrukkelijke bedoeling dat de rechter daar via maatwerk invulling aan kan geven. ${ }^{6}$ Andersom zegt de rechter soms dat het niet tot zijn rechtsvormende taak behoort om een bepaald probleem op te lossen, en dat is een signaal dat de wetgever aan zet is. ${ }^{7}$

2 Zie mijn artikel 'Development of the Law by Supreme Court in Europe', Utrecht Law Review 2017, p. 155 e.v., https://www.utrechtlawreview.org/articles/abstract/10.18352/ulr.401. Een tegengeluid is te beluisteren bij C.A.J.M. Kortmann in W.M.T. Keukens e.a. (red.), Raad en Daad. Over de rechtsvormende taak van de Hoge Raad, Nijmegen 2008, p. 32-33.

3 EHRM 3 februari 2015, Hutchinson vs. United Kingdom, no. 57592/08, par. 24.

4 'Wetgever en (cassatie)rechter, beiden zijn ze verantwoordelijk voor het onderhouden van het rechtssysteem', aldus S.K. Martens, de latere president van de Hoge Raad, in: De Hoge Raad der Nederlanden 1838-1988, Zwolle 1988, p. 154.

5 Zie bijvoorbeeld H.U. Jessurun d'Oliveira in: Speculum Langemeijer, p. 241 (die spreekt over de rechter als partner in de regelgeving) en J.B.M. Vranken, NJB 2000, p. 5. J.M. van Dunné, WPNR 1989/5905, p. 108, spreekt over een rol van de rechter als hulpwetgever.

6 Een mooi voorbeeld is art. 3.25 van de Wet op de inkomstenbelasting 2001: de in een kalenderjaar genoten winst van een ondernemer wordt bepaald volgens goed koopmansgebruik.

7 Zie de rechtspraak die hierna wordt vermeld in noot 24. 
Gelukkig zijn de verhoudingen tussen wetgever en rechter in Nederland in het algemeen goed. Dat komt de kwaliteit van de rechtsstaat, van zowel wetgeving als rechtspraak, ten goede. Dat is iets om te koesteren.

\section{Signalen van de rechter aan de wetgever, algemeen}

Eén aspect van de omgang tussen wetgever en rechter wil ik nader met $\mathrm{u}$ bespreken, namelijk signalen van de Hoge Raad aan de wetgever. Wij komen bij de behandeling van zaken zo nu en dan onvolkomenheden in wettelijke regels tegen. Meestal betreft dan het kwesties van technische aard. Denkt u vooral niet dat wij voortdurend zitten te mopperen op de wetgever en de kwaliteit van uw werk, integendeel. Zoals ik al zei, wij zijn ons heel goed ervan bewust hoe moeilijk het wetgevende vakwerk is, en zien met die kennis dus ook hoe hoog de kwaliteit van de regelgeving in ons land over het algemeen is, zeker op nationaal niveau. De Academie voor Wetgeving levert daaraan ook een belangrijke bijdrage. Wij realiseren ons ook dat de kwesties die bij de Hoge Raad komen niet representatief zijn voor het complete recht en de gehele wetgeving in Nederland. Er zijn veel regels die nauwelijks vragen of technische kritiek oproepen. Daarmee krijgen wij niet of niet zo vaak te maken. Het zijn vooral de juridische probleemgevallen die tot aan de Hoge Raad worden uitgeprocedeerd.

Als ons dingen opvallen in regelgeving, spreken wij daar natuurlijk met elkaar over onder het werk, aan de lunch en dergelijke. Al geruime tijd leefde de vraag of de leden van de Hoge Raad dat verder voor zich moeten houden, of dat we er in het belang van een goede wetgeving iets mee zouden moeten doen. Tot voor kort gebeurde dat niet, in ieder geval niet systematisch. Wel kwam het al incidenteel voor dat de Hoge Raad zulke signalen gaf. Ik noem de volgende arresten:

- het arrest over kroongetuigen uit 1998, waarvan de boodschap kort samengevat luidde: de wetgever moet dat thema regelen, maar als het te lang duurt, voelen wij ons daartoe wellicht genoodzaakt';

- het arrest uit 2014, waarin de Hoge Raad een duidelijk signaal heeft gegeven in de richting van de wetgever met betrekking tot de aanwezigheid van een advocaat bij het politieverhoor. De HR overwoog dat het op de weg van de wetgever ligt de invoering van de vereiste wettelijke regeling 'met voortvarendheid ter hand te nemen'. ${ }^{9}$

Het is ook wel voorgekomen dat de Hoge Raad - voorzichtige - signalen aan de wetgever gaf in zijn jaarverslagen. ${ }^{10}$

10 Zie het jaarverslag van 2014, onderdeel Belastingkamer, p. 42 onder 'Class action', en het jaarverslag van 2013, onderdeel Civiele kamer, p. 9 en 10. 
In de literatuur is terugkoppeling door rechter naar de wetgever ook aantal keren aan de orde gesteld, de meningen daarover waren verdeeld. ${ }^{11}$ De Hoge Raad bleef terughoudend.

\section{Argumenten voor en tegen}

Deze terughoudendheid van de Hoge Raad ten aanzien van het geven van signalen naar de wetgever berustte op een aantal tegenargumenten, althans redenen voor aarzeling: ${ }^{12}$

- De rechter moet oppassen dat zijn functioneren als onafhankelijke en onpartijdige instantie niet in gevaar komt, bijvoorbeeld door het leveren van kritiek op beleidskeuzen van de wetgever.

- De rechter moet geen branchevreemde activiteiten naar zich toetrekken. Hij is er niet om het huiswerk van de wetgever te maken, dat moet de wetgever zelf doen.

- De rechter kan zeker niet in algemene zin de verantwoordelijkheid voor de kwaliteit van de wetgeving dragen.

- Een wetstechnisch argument was verder dat de regeling over advisering door de Hoge Raad in (thans) art. $74 \mathrm{RO}$ aldus verstaan zou moeten worden dat de Hoge Raad niet de bevoegdheid heeft om ambtshalve advies of inlichtingen aan de wetgever te geven.

De Hoge Raad heeft echter aanleiding gezien om zijn zeer terughoudende opstelling te heroverwegen. Aanleiding daarvoor waren onder meer gesprekken die ik heb gevoerd met bewindspersonen, leden van de Tweede Kamer en leidinggevende ambtenaren van ministeries. Bij herhaling beluisterde ik daarin aansporingen aan de Hoge Raad om hier wel wat mee te doen in het belang van de kwaliteit van de wetgeving. Zoals we zelf binnen de Hoge Raad ook ter verbetering van de kwaliteit aan reflectie doen, en bijvoorbeeld kritische commentaren op recente arresten bespreken. Naar aanleiding daarvan stellen wij ons telkens de vraag: hebben we iets gemist, en zou het een volgende keer anders, duidelijker, uitgebreider moeten? Ook houdt de HR jaarlijks een refereerbijeenkomst met externe sprekers, aan wie gevraagd wordt om commentaar te leveren op het (in hun ogen) beste en slechtste arrest van het jaar.

Er zijn dan ook verschillende argumenten die pleiten voor het geven van signalen aan de wetgever door de Hoge Raad:

11 P.J. van Amersfoort, Regelmaat 2006, p. 197 e.v.; W.D.H. Asser, Trema 1981, p. 51 e.v.; E. Baauw, Regelmaat 2006, p. 203 e.v.; W.J.M. Davids, Communicatie tussen de wetgevende en rechterlijke macht, voordracht voor de Academie voor Wetgeving, 2006; R.A.J. van Gestel, 'Schurende of samenwerkende machten', in: De wetgevingsadvisering door de Raad van State, Preadviezen voor de Vereniging voor Wetgeving en Wetgevingsbeleid, Nijmegen 2008; I. Giesen \& H.N. Schelhaas, AA 2006, p. 159 e.v.; J.L.M. Gribnau, A.O. Lubbers \& H. Vording, WFR 2009, p. 675 e.v.; A. Hartkamp, NJB 1986, p. 1027 e.v.; J. de Hullu, NJB 2002, p. 301 e.v.; J.H. van Kreveld, Regelmaat 2006, p. 186 e.v.; J.M. Polak, Adviseren en rechtspreken, Enkele beschouwingen over functionele en organisatorische combinaties, 1977, p. 373 e.v.; J.M. Polak, in Speculum Langemeijer, Zwolle 1973, p. 416 e.v. 
- Met name is een belangrijk inhoudelijk argument dat met zulke signalen in het algemeen belang een nuttige bijdrage kan worden geleverd aan de kwaliteit van wetten, waaronder ook de uitvoerbaarheid. Die kwaliteit draagt ook bij aan de rechtszekerheid, aan beperking van het aantal processen en aan het gezag van de wet. De signalering dient aldus een breder algemeen belang, zij kan gezien worden als een nuttige service aan de samenleving.

- Te veel vrees dat de onafhankelijkheid van de rechter hierdoor wordt aangetast, is in de ogen van verschillende auteurs ongegrond. ${ }^{13}$ Zo was de conclusie van Jim Polak dat je hier 'niet te schroomvallig' tegenaan moet kijken.

- De bepaling in de Wet RO over advisering door de Hoge Raad kan zo worden opgevat dat zij hier wel de ruimte voor biedt. ${ }^{14}$

- Asser wees er ook op dat signalen van de HR aan de wetgever de basis kunnen vormen voor een vruchtbare gedachtewisseling met politiek en samenleving. ${ }^{15}$

\section{Ervaringen elders}

Het is van belang ons te realiseren dat het geen uniek en revolutionair idee is als de hoogste rechter signalen geeft aan de wetgever:

- Zo kent Frankrijk hiervoor al een wettelijke regeling sinds de Grondwet van het jaar VIII (niet de Christelijke maar de revolutionaire jaartelling). Historisch is dit te verklaren door de nauwe band die oorspronkelijk werd gelegd tussen de wetgevende macht en de Franse cassatie-instantie. Die band is inmiddels verbroken, maar de wettelijke regeling over het signaleren van problemen in de wetgeving is gebleven. De president van het Franse Hof van Cassatie en de procureur-generaal kunnen de aandacht van de minister van Justitie vragen voor kwesties die het Hof van Cassatie heeft opgemerkt bij de behandeling van zaken. Zij kunnen ook verbeteringen noemen die volgens hen de geconstateerde problemen zouden oplossen. ${ }^{16}$ Dat gebeurt standaard in het jaarverslag van het Cour de Cassation, daaraan worden jaarlijks tientallen bladzijden gewijd.

- In België is het geven van signalen aan de wetgever de taak van de procureurgeneraal bij het Hof van Cassatie en het College van procureurs-generaal. Het jaarlijks uit te brengen verslag aan een parlementair comité moet een overzicht bevatten van wetten die voor hoven en rechtbanken moeilijkheden bij de toepassing en interpretatie daarvan hebben opgeleverd. ${ }^{17}$

J.M. Polak, in Adviseren en rechtspreken, 1977, p. 373 e.v., en J.M. Polak, in Speculum Langemeijer, 1973, p. 416 e.v.

14 J.M. Polak, in Adviseren en rechtspreken, 1977, p. 373 e.v.

15 W.D.H. Asser, 'Rechterlijke onafhankelijkheid en politiek', Trema, 1981, p. 51.

16 Zie art. 431-10 van de Code de l'organisation juridique. Zie ook M. Adams, NJB 2009, p. 1439 e.v.

17 Art. 11 van de Wet van 25 april 2007 tot oprichting van een Parlementair Comité belast met de wetsevaluatie. Zie hierover ook L. Huybrechts in N. Huls e.a. (red.), The Legitimacy of Highest Court's Rulings, Judicial Deliberations and Beyond, Den Haag 2009, p. 192. 
- Ook in Oostenrijk blijkt uit een recent jaarverslag (over 2016) van het Hooggerechtshof dat het de wetgever heeft gewezen op problemen in de wetgeving waartegen het bij de behandeling van zaken is aangelopen. ${ }^{18}$ Bovendien worden in Oostenrijk regelmatig wetgevingsadviezen gegeven door het Oberste Gerichtshof (OGH), dat daarvoor zogenoemde Begutachtungssenaten kent. $^{19}$

In Nederland houdt het onderwerp terugkoppeling naar de wetgever ook de Raad van State bezig. In 2005 is een symposium gewijd aan het onderwerp, ${ }^{20}$ en mede naar aanleiding daarvan is destijds besloten tot een meer systematische terugkoppeling naar de wetgever op basis van de ervaringen bij de Afdeling bestuursrechtspraak. Dat terugkoppelen kwam maar moeilijk van de grond. Thans probeert men het project bij de Raad van State nieuw leven in te blazen. Dat gebeurt via een laagdrempelige melding vanuit de Afdeling bestuursrechtspraak, waarna het signaal gegeven moet worden door de Afdeling wetgevingsadvisering. ${ }^{21}$

\section{Besluit van de Hoge Raad om ermee aan de slag te gaan}

In de tweede helft van het vorig jaar hebben we bij de Hoge Raad, na afweging van de eerder besproken voor- en nadelen, besloten om een wat actievere rol te gaan nemen bij het signaleren van knelpunten in de wetgeving. Ik heb dit vorig jaar naar buiten gebracht in een installatierede en in een interview met SC naar aanleiding daarvan. ${ }^{22}$ In het onlangs verschenen jaarverslag van de Hoge Raad over 2017 staat een overzicht van de belangrijkste arresten uit dat jaar met signalen aan de wetgever. ${ }^{23} \mathrm{Zo}$ zijn die signalen voor iedere geïnteresseerde toegankelijk zonder dat men daarvoor de complete rechtspraak van de Hoge Raad moet doornemen.

Uitgangspunt bij deze keuze van de Hoge Raad voor een actievere rol is dat de vorming van werkbare en evenwichtige rechtsregels een gezamenlijke verantwoordelijkheid is van wetgever en rechter. In een flink deel van de gevallen zorgt de rechter zelf voor de oplossing als de wettelijke regeling een onvolkomenheid of zelfs een tekortkoming bevat. Maar dan nog kan het voor rechtzoekenden beter zijn dat zij in de toekomst de oplossing in de wet zelf kunnen vinden. Een oplossing door de rechter is bovendien niet altijd mogelijk; zijn rechtsvormende taak is

18 http://www.ogh.gv.at/media/ogh_taetigkeitsbericht_2016-web-es.pdf, zie p. 20.

$19 \S 11$ van het OGH-Gesetz. 'Aufgabe dieser Senate ist es, auf Ersuchen des Bundesministers für Justiz oder des Präsidenten des Obersten Gerichtshofes zu Gesetzes- oder Verordnungsentwürfen Gutachten abzugeben.'

20 Naar aanleiding van dit symposium is door de Raad van State een boek uitgebracht: H.D. Tjeenk Willink e.a. (red.), Terugkoppelen naar de wetgever, Den Haag 2006. Zie ook Kamerstukken II 2005/06, 30300 VI, nr. 169.

21 Zie de bijdrage aan deze aflevering van J.J. van Eck en R.K. Visser op p. 380.

22 Zie https://www.rechtspraak.nl/Organisatie-en-contact/Organisatie/Hoge-Raad-der-Nederland en/Nieuws/Paginas/President-en-procureur-generaal-wijzen-op-het-belang-van-rechtstatelijkewaarden.aspx en SC online 24 november 2017, http://www.sconline.nl/interview/\%E2\%80\%98 wetgever-kan-natuurlijk-niet-alles-tot-detail-regelen\%E2\%80\%99. 
begrensd. Waar de rechter de oplossing niet kan bieden, is de kwaliteit van het recht erbij gebaat dat de wetgever dat doet. Hoe sneller de wetgever in kennis wordt gesteld van een dergelijk probleem, des te eerder zou het opgelost kunnen worden. En in gevallen waarin de wetgever een dergelijk signaal niet oppakt, kan de omstandigheid dat het signaal expliciet door de Hoge Raad is gegeven de oplossing dichterbij brengen: die omstandigheid kan dan een legitimerend effect hebben op eigen rechtsvorming door de Hoge Raad, als hij vervolgens voor de beslissing staat of hij het probleem toch maar zelf moet oplossen. De Hoge Raad heeft ook een aantal keren bij het geven van een signaal aan de wetgever als schot voor de boeg te kennen gegeven dat hij (mogelijk) zelf de oplossing zou gaan bieden als de wetgever dat niet doet. ${ }^{24}$

\section{Begrenzingen}

Ook bij de huidige werkwijze met signalen aan de wetgever is terughoudendheid het uitgangspunt bij de Hoge Raad. Wij zijn ons goed bewust van de mogelijke nadelen en risico's, met name vanwege de verschillende taken en verantwoordelijkheden van de wetgevende en de rechterlijke macht. De rechterlijke macht verwijt politici soms dat zij op de 'stoel' van de rechter gaan zitten; dan moeten rechters vice versa niet hetzelfde doen.

Onze bedoeling is dan ook om ons vooral te richten op juridische signalen, en ons niet in te laten met politieke en beleidsmatige keuzes. Dat laatste doen we ook niet in onze rechtspraak. Deze beperking sluit ook aan bij de manier waarop de president van en de procureur-generaal bij de Hoge Raad hun adviserende taak afbakenen bij voorgenomen wetgeving. ${ }^{25}$ Het in de literatuur gesignaleerde risico dat de onafhankelijkheid en onpartijdigheid van de rechter in gevaar komen, willen wij op die manier vermijden. Het zal dus vooral gaan om juridisch-technische aspecten van wetgeving. Daarbij valt te denken aan hiaten in de wet, tekortschietend overgangsrecht, vergissingen (bijvoorbeeld verkeerde artikelverwijzingen), onvoldoende afstemming tussen verschillende regelingen, ${ }^{26}$ innerlijke tegenstrijdigheden en andere inconsistenties, en strijd van lagere regeling met hogere. Diverse voorbeelden van dit alles zijn te vinden in het overzicht in ons jaarverslag over 2017, ik kom daarop dadelijk terug in paragraaf 10.

Wij hebben stilgestaan bij de vraag of we ook signalen zullen geven als de praktische uitvoerbaarheid en de conflictgevoeligheid van wetgeving tot problemen leiden. Dat zijn ook problemen waar een rechter mee geconfronteerd wordt, waar hij last van kan hebben, en het raakt op zichzelf niet aan politieke keuzes. Maar wij realiseren ons ook dat wij als hoogste rechter maar het topje van de ijsberg zien. Als we het idee hebben dat een regeling praktische problemen geeft of con-

24 Bijvoorbeeld in het hiervoor in punt 2 besproken arrest over kroongetuigen, en het hierna in punt 10 te bespreken arrest over discriminatie in bijstandszaken. Zie ook reeds het arrest van de Belastingkamer van 31 januari 1990, BNB 1990/288, AB 1990/365.

25 Zie daarover W.J.M. Davids, interview in NJB 2006, p. 2241.

26 Denk aan procesrecht Antilliaanse belastingzaken en griffierecht. 
flictgevoelig is, zullen we dat in principe alleen melden bij de Raad voor de Rechtspraak, omdat feitenrechters daar een vollediger beeld van hebben. De Raad voor de Rechtspraak kan dit signaal dan eventueel, in combinatie met de ervaringen van feitenrechters, meenemen in een spontaan of gevraagd wetgevingsadvies. ${ }^{27}$

Het zal wel moeten gaan om gevallen waarin er naar het oordeel van de Hoge Raad voldoende reden is voor signalering, in die zin dat hij het echt als een probleem ziet en niet als een schoonheidsfout(je). De Hoge Raad zal met andere woorden selectief moeten zijn. Hij moet geen zout strooien op een groot aantal juridische slakjes. Maar je moet het per geval goed bekijken: juridisch-technische onvolkomenheden die voor een groter publiek misschien weinig spectaculair zijn, kunnen voor direct betrokkenen heel storend uitwerken, ook al gaat het om een (ogenschijnlijk) detail. Dan kan een signaal aan de wetgever toch nuttig zijn. Een goed voorbeeld vormt het overgangsrecht bij indexatie van de normbedragen voor proceskostenvergoedingen. ${ }^{28}$ Niet spectaculair, maar voor rechters is het dagelijks aan de orde.

Het heeft geen zin water naar de zee te dragen. Als de wetgever al bezig is om het probleem op te lossen of dat van plan is, zal signalering van dat probleem door de Hoge Raad in het algemeen geen toegevoegde waarde hebben.

Vooralsnog willen we de signalering beperken tot landelijke wetgeving, en richten we ons dus niet op verordeningen van provincies, gemeenten en waterschappen.

Tot slot: wij zullen de signalering beperken tot problemen waartegen de Hoge Raad bij het behandelen van een concrete zaak aanloopt. ${ }^{29}$ Dat betekent dat onze ambities op dit gebied beperkt zijn. Het is niet de bedoeling van de Hoge Raad om hiermee een nieuwe taak aan zich te trekken. Het gaat om het vastleggen van kwesties die we toch al geconstateerd hebben, veelal tijdens de bespreking van een zaak in raadkamer. Bij inachtneming van die beperking denk ik dat je deze signalering ook niet als een branchevreemde activiteit van de rechter kunt beschouwen. Het is zeker niet de bedoeling dat de Hoge Raad een algehele verantwoordelijkheid op zich neemt voor de kwaliteit van wetgeving, en aldus alle mogelijke gebreken en andere knelpunten in de gehele wetgeving wil gaan signaleren en terugkoppelen. Goede wetgeving is de primaire verantwoordelijkheid van de wetgever, en dat moet ook vooral zo blijven.

\section{Organisatorisch}

Omdat we op dit punt het bewustzijn binnen de Hoge Raad willen vergroten, en willen voorkomen dat nuttige gedachten meteen verdampen, zijn in iedere sector

De adviserende taak van de Raad voor de Rechtspraak is vastgelegd in art. 95, lid 1 Wet RO. Zie ook E. Bauw, RegelMaat 2006/6, p. 203 e.v. en https://www.rechtspraak.nl/Organisatie-encontact/Organisatie/Raad-voor-de-rechtspraak/Wetgevingsadvies. 
een raadsheer en een advocaat-generaal aangewezen die hier extra op letten. Bij de zaken die in raadkamer langskomen, zal de betrokken raadsheer er extra op letten of in het debat tussen de raadsheren (mogelijke) signalen aan de wetgever voorbijkomen.

\section{Vorm van de signalering}

Ter signalering van serieuze knelpunten in de wetgeving zijn arresten het meest natuurlijke communicatiemiddel voor de Hoge Raad. Het risico dat de raad zich een branchevreemde activiteit zou aanmeten, wordt door de inbedding in arresten ook beperkt. Bij vaststelling in een arrest is langs geëigende procedureregels vastgesteld dat de boodschap het oordeel van de Hoge Raad weergeeft. Een voordeel van signalering in arresten is ook dat deze meteen openbaar zijn: alle arresten met juridisch relevante overwegingen worden de dag waarop zij worden uitgesproken op internet gepubliceerd. Signalen die in deze vorm worden gegeven zijn daarmee volledig transparant. Zij zijn daarmee ook kenbaar voor anderen dan bewindspersonen en hun ambtenaren, zoals de academische wereld, andere belanghebbenden, Kamerleden, journalisten etc.

Voor het overzicht neemt de Hoge Raad na afloop van het jaar in zijn jaarverslag een samenvatting op van de belangrijkste arresten waarin zulke signalen te vinden zijn. Dat is onlangs voor het eerst gebeurd in het verslag over 2017 (zie paragraaf 10). Ook dat verslag is openbaar, het wordt op internet geplaatst. Overigens is het zeker niet onze bedoeling om dat overzicht het karakter te geven van een zwarte lijst, het is geen ranglijst met de slechtste wetten van het jaar. De signalering is opbouwend bedoeld. In de inleiding bij ons laatste jaarverslag is ook een positieve toon over de kwaliteit van Nederlandse wetten vooropgesteld. In België en Frankrijk kent men al jaren lang zulke overzichten (zie paragraaf 4) en daar bestaat ook niet het sentiment dat de hoogste rechter of het parket daarmee de wetgever bekritiseert.

Wekelijks publiceert de Hoge Raad vele tientallen arresten. Wij zijn ons ervan bewust dat niet iedere geïnteresseerde, ook niet op wetgevende afdelingen, meteen alle arresten van de Hoge Raad leest met het oog op mogelijke signalen aan de wetgever. Per geval zullen we daarom bekijken of zo'n signaal nog extra aandacht vraagt voordat ons jaarverslag verschijnt, waarbij wij ons bovendien realiseren dat ook niet iedereen die met wetgeving te maken heeft ons jaarverslag spontaan helemaal doorneemt. Bij zulke aanvullende signalen valt te denken aan een persbericht over het arrest, of aan toezending van het arrest met een kort begeleidend briefje aan de betrokken minister waarin de aandacht op het arrest wordt gevestigd. Zo is er het afgelopen jaar een persbericht verschenen naar aanleiding van diverse arresten met signalen aan de wetgever. ${ }^{30}$ Ook heb ik een briefje geschreven aan de minister van Sociale Zaken en Werkgelegenheid om de aandacht te vestigen op een arrest waarin was beslist dat het aan de wetgever is

30 Verwijzingen naar die persberichten staan in het jaarverslag van de HR over 2017, bij het overzicht van arresten met signalen aan de wetgever. 
om een einde te maken aan een bepaalde, met verdragsrecht strijdige discriminatie in de bijstandswetgeving. ${ }^{31}$

\section{Hoe vaak?}

Hoe vaak zal het voorkomen dat de Hoge Raad zulke signalen geeft in een arrest? We hebben hiervoor niet een voorgenomen quotum als doelstelling. Het hangt ervan af waar we spontaan tegenaan lopen en of we het van voldoende belang vinden om er in het arrest iets over te zeggen. Ik schat in dat het zal gaan om 10 tot 20 gevallen per jaar. Het jaarverslag over 2017 bevat 14 vermeldingen. ${ }^{32}$ Misschien worden het er in volgende jaren wat meer dan in 2017 , door een geleidelijke bewustwording binnen de HR. Zoals Johan Cruijff zei: je gaat het pas zien als je het doorhebt. Maar ik verwacht dat het in deze orde van grootte zal zijn.

\section{Voorbeelden in het jaarverslag over 2017}

In het jaarverslag van de Hoge Raad over 2017 staat een overzicht van signalen aan de wetgever in arresten uit dat jaar. Het zijn vrijwel allemaal juridisch-technische kwesties.

- In zeven gevallen signaleerde de Hoge Raad een leemte in de wetgeving:

- Eén geval betrof een onvolledige verwijzing naar toepasselijke regels van procesrecht in een fiscale invorderingszaak. De Invorderingswet 1990 verklaarde bijzondere regels uit de AWR van overeenkomstige toepassing op dit soort procedures, maar zweeg over de vraag welke algemene regels hier gelden. In dit geval loste de Hoge Raad het zelf op door aan te nemen dat ook de algemene regels in Hoofdstuk 6 Awb in deze procedures van overeenkomstige toepassing zijn. ${ }^{33}$

- In een civiele zaak over de nationaliteit van een kind uit een bigaam huwelijk constateerde de Hoge Raad dat de Rijkswet op het Nederlanderschap niet voorziet in de situatie na ontbinding van zo'n huwelijk. De Hoge Raad volstond met het signaal dat dit resultaat onbevredigend is, gezien de gedachte achter de bestaande regels. ${ }^{34}$

- In twee zaken over digitaal procederen constateerde de Hoge Raad dat de wet de onderhavige situatie niet regelt, en gaf de raad daarvoor zelf de oplossing. ${ }^{35}$ Ten aanzien van de nieuwe uiterste datum voor het indienen van een processtuk door de wederpartij na een herstelde procesinleiding

31 Met een kopie aan de minister voor Rechtsbescherming in verband met diens overkoepelende verantwoordelijkheid voor wetgevingskwaliteit. Dit betrof het arrest HR 8 december 2017, ECLI:NL:HR:2017:3081, AB 2018/126.

32 Vijf arresten van de civiele kamer, vier van de strafkamer en vijf van de belastingkamer.

33 HR 8 december 2017, ECLI:NL:HR:2017:3084, BNB 2018/30.

34 HR 9 mei 2017, ECLI:NL:HR:2017:942, NJ 2017/435.

35 HR 13 oktober 2017, ECLI:NL:HR:2017:2628, NJ 2017/419 en HR 13 oktober 2017, ECLI:NL:HR:2017:2629, NJ 2017/420. 
staat in het jaarverslag dat de Hoge Raad vindt dat dit in de wet behoort te staan.

- De strafkamer constateerde dat de verplichting voor een advocaat om zich bij de rechtbank te stellen met ingang van 1 maart 2017 uit de wet is gehaald. ${ }^{36}$ 'Om onnaspeurbare redenen' aldus het jaarverslag. In het arrest wordt opgemerkt 'dat de tegenwoordige regeling licht aanleiding kan geven tot fouten en misverstanden' en dat 'uit niets blijkt dat de wetgever dit risico onder ogen heeft gezien en nog minder dat hij dit heeft aanvaard'. In het arrest creëerde de Hoge Raad zelf een oplossing, een noodvoorziening noemde hij dit in het jaarverslag. Dit is dus te zien als een signaal aan de wetgever dat een en ander wel in de wet geregeld zou moeten worden.

- In die sfeer past ook het arrest van de strafkamer over opsporingsonderzoek aan een in beslag genomen smartphone. De huidige wet regelt dat niet expliciet. In deze zaak wees de HR de weg, in afwachting van nieuwe wetgeving op dit punt. ${ }^{37}$

- In een arrest over voorwaardelijke strafrechtelijke veroordelingen constateerde de Hoge Raad dat de status van voorwaarden die uitvoerbaar bij voorraad zijn, niet in de wet is geregeld. ${ }^{38}$ Ook hier wees de raad zelf de weg. Hij gaf daarbij het signaal dat het gaat om 'wetgeving van complexe aard, waarvan de uitwerking op onderdelen vragen oproept'. In dit geval signaleerde de Hoge Raad dus wel zelf dat de wet onduidelijk is.

- In een civiel arrest over kosten van een faillissement constateerde de Hoge Raad een anderszins onbevredigende situatie, en zei daarbij dat het bieden van een oplossing daarvoor de rechtsvormende taak van de rechter te buiten gaat. ${ }^{39}$

- In een arrest over het horen van anonieme getuigen in het bestuursrecht overwoog de Hoge Raad dat wettelijke regels daarover ontbreken en dat het daardoor onzeker is of anoniem horen überhaupt wel mogelijk is. De Hoge Raad roept in het arrest de vraag op of het niet eerder op de weg van de wetgever ligt om hieromtrent regels te stellen. Over de vraag of een dergelijke regeling al dan niet wenselijk is, laat de raad zich hierbij niet uit. ${ }^{40}$ 
- Twee fiscale arresten bevatten signalen aan de wetgever op het gebied van het overgangsrecht. ${ }^{41} \mathrm{Op}$ fiscaal gebied lijkt het overgangsrecht een wat ondergeschoven kindje te zijn. ${ }^{42}$

- Drie arresten constateerden een inbreuk op een regeling van hogere orde. Ze tonen drie varianten voor de aanpak van een dergelijke strijd door de rechter:

- In een arrest over het partnerbegrip in de bijstandswetgeving constateerde de Hoge Raad een inbreuk op het verbod van discriminatie, maar besloot hij vooralsnog ${ }^{43}$ niet in te grijpen, omdat de discriminatie op verschillende manieren kan worden opgelost en het aan de wetgever is om daaruit een keus te maken. ${ }^{44}$

- In een arrest over levenslange gevangenisstraf constateerde de strafkamer van de Hoge Raad een inbreuk op art. 3 EVRM, en besloot hij de beslissing ruim een jaar aan te houden in afwachting van aangekondigde regelgeving die beoogde om de tenuitvoerlegging van deze straf in Nederland in overeenstemming te brengen met de eisen van het EVRM. Toen die regeling tot stand was gekomen, toetste de Hoge Raad de nieuwe situatie aan art. 3 EVRM en kwam hij tot de slotsom dat er geen sprake (meer) was van een schending van deze verdragsbepaling. ${ }^{45}$

- Ten aanzien van Arubaans namenrecht had de Hoge Raad ruim 19 jaar eerder al aangenomen dat de wettelijke regeling daar discriminerend was. Toen had de Hoge Raad nog niet ingegrepen en de oplossing aan de wetgever overgelaten. De wetgever op Aruba had inmiddels wel een regeling getroffen, maar die was nog niet in werking getreden. In dit geval greep de Hoge Raad wel in, overeenkomstig de nog niet in werking getreden wettelijke regeling. ${ }^{46}$

Het is de vraag of uit dit overzicht patronen zijn af te leiden en of daaruit lessen getrokken kunnen worden. Een algemene constatering, die niet alleen op dit jaar terugslaat, is dat overgangsrecht extra aandacht verdient. Verder kan worden opgemerkt dat er meer risico op tekortkomingen bestaat bij wetgeving die snel en onder grote druk tot stand moet komen. Dat geldt in het bijzonder voor fiscale wetten, die vaak tussen Prinsjesdag en 1 januari van het nieuwe jaar tot stand

41 HR 20 oktober 2017, ECLI:NL:HR:2017:2656 , BNB 2018/5, en HR 8 december 2017, ECLI:NL:HR:2017:3083, BNB 2018/50.

42 Reeds in het jaarverslag over 2015 (p. 38) signaleerde de HR dat zich in belastingzaken met regelmaat moeilijkheden voordoen als gevolg van ontbrekend of ontoereikend overgangsrecht. Zie ook de in het afgelopen jaar gewezen arresten van 24 februari 2017, ECLI:NL:HR:2017:289, BNB 2017/134 en van 3 maart 2017, ECLI:NL:HR:2017:356, BNB 2017/105. De Raad van State vroeg al in 2005 in algemene extra aandacht voor (tekortschietend) overgangsrecht, zie Kamerstukken II 2005/06, 30300 VI, nr. 169, p. 4 e.v.

43 'Voor ingrijpen van de rechter kan wel aanleiding bestaan indien de wetgever na kennisneming van dit arrest nalaat zelf een regeling te treffen die de discriminatie opheft', aldus het arrest.

44 HR 8 december 2017, ECLI:NL:HR:2017:3081, AB 2018/126.

45 HR 19 december 2017, ECLI:NL:HR:2017:3185, RvdW 2018/135.

46 HR 13 oktober 2017, ECLI:NL:HR:2017:2614, NJ 2018/43. 
moeten komen. Ook is er meer risico op technische fouten bij amendementen, ${ }^{47}$ die eveneens onder grote tijdsdruk tot stand plegen te komen. Het hiervoor genoemde arrest over de bijstand, waarin de HR een schending van het discriminatieverbod heeft aangenomen, betrof ook een bij amendement ingevoerde wetsbepaling. Juist vanwege het discriminerende karakter had de regering dat amendement nota bene ontraden.

\section{Oplossingen voorstellen?}

De Hoge Raad zal in het algemeen niet zelf gaan suggereren hoe een tekortkoming in regelgeving is op te lossen. Zo'n keuze is immers al snel politiek of beleidsmatig van aard. Dat is vaak juist de reden voor de Hoge Raad om niet in grijpen als rechter. Zo plegen wij in wetgevingsadviezen ook geen suggesties te doen over welke keuze de wetgever zou moeten maken. Ook op deze manier streven wij ernaar om de onafhankelijkheid en onpartijdigheid van de rechter niet in gevaar te brengen. Een voorbeeld is het arrest over de vraag over het horen van anonieme getuigen in het bestuursrecht. ${ }^{48}$ De Hoge Raad constateert in het arrest dat wettelijke regels hierover ontbreken en dat het daardoor onzeker is of anoniem horen überhaupt wel mogelijk is. Daar voegde de Hoge Raad aan toe dat onder ogen moet worden gezien of het niet eerder op de weg van de wetgever ligt om hieromtrent regels te stellen. Over de vraag of de mogelijkheid tot het horen van anonieme getuigen in deze zaken inderdaad geboden moet worden, liet de Hoge Raad zich niet uit.

Maar soms ligt de oplossing erg voor de hand. Dan kan het zijn dat de Hoge Raad die oplossing ook benoemt. Ook kan het ook zinvol zijn om een aantal mogelijke oplossingsrichtingen te benoemen zonder een voorkeur uit te spreken. In wetgevingsadviezen doen de president van en de procureur-generaal bij de Hoge Raad soms ook wel zulke suggesties. Maar terughoudendheid is hier toch de grondhouding. Daarvan uitgaande zie ik ook geen strijd met art. 74 en 120, lid 1 van de Wet $\mathrm{RO}$, waarin trouwens alleen geregeld is in welke gevallen de Hoge Raad en leden van het parket van de procureur-generaal verplicht zijn op verzoek advies uit te brengen aan de minister.

\section{Follow-up?}

Het jaarverslag van de Franse Cour de Cassation bevat een overzicht van wat er met zijn eerdere aanbevelingen aan de wetgever is gebeurd. Daarvan blijkt overigens een aanzienlijk deel (nog) niet te zijn opgevolgd. Sommige punten komen aldus bij herhaling in het jaarverslag terug. Ook in Oostenrijk zie je dat het Ober-

47 In 2005 wees de Raad van State op het belang dat de amendering van wetsvoorstellen zorgvuldig wordt begeleid, zie Kamerstukken II 2005/06, 30300 VI, nr. 169, p. 6. In zijn oratie constateerde Happé dat de gevallen waarin de belastingrechter discriminatie aannam vooral amendementen betroffen, zie R.H. Happé, Schuivende machten, over trias politica en het gelijkheidsbeginsel in het belastingrecht (oratie Tilburg) 1999. 
ste Gerichtshof in zijn jaarverslag erop terugkomt als de wetgever geen gevolg geeft aan zijn suggesties met betrekking tot wetgeving. ${ }^{49}$ De Hoge Raad heeft nog niet besloten of hij in de toekomst systematisch wil gaan monitoren in hoeverre de wetgever zijn signalen heeft opgepikt. Wij zijn overigens benieuwd hoe betrokkenen, zoals wetgevingsambtenaren, daartegen aankijken. In gevallen waarin de Hoge Raad niet heeft ingegrepen vanwege de beperkte rechtsvormende taak van de rechter, bestaat de mogelijkheid dat hij in de toekomst alsnog ingrijpt als de wetgever het signaal niet oppakt. ${ }^{50}$ Ook dat is een vorm van follow-up naar aanleiding van signalen aan de wetgever.

\section{Slot}

Hiermee kom ik tot een afronding van mijn toelichting op de nieuwe koers van de Hoge Raad bij het geven van signalen aan de wetgever. Een voorzichtige en dienstwillige koers, waarbij goede communicatie en afstemming met de wetgever ons uitgangspunt is, met begrip en respect voor elkaars te onderscheiden bevoegdheden.

49 Tätigkeitsbericht 2016, http://www.ogh.gv.at/media/ogh_taetigkeitsbericht_2016-web-es.pdf, p. 20: 'Mit Bedauern muss die Vollversammlung des Obersten Gerichtshofs nach wie vor zur Kenntnis nehmen, dass der Gesetzgeber bisher nicht auf ihr mehrfach geäußertes Anliegen reagiert hat, die Regelungen des OGH-Gesetzes (OGH-G) über den verstärkten Senat in zwei Punkten zu modifizieren.'

50 Zie de rechtspraak bedoeld in noot 24. In de zaak over het Arubaanse namenrecht, besproken in punt 10 hiervoor, greep de HR na verloop van tijd inderdaad alsnog in. 